\title{
Characterization of Advanced Preprocessed Materials (Hydrothermal)
}

\author{
Rachel Emerson \\ Garold Gresham
}

September 2012

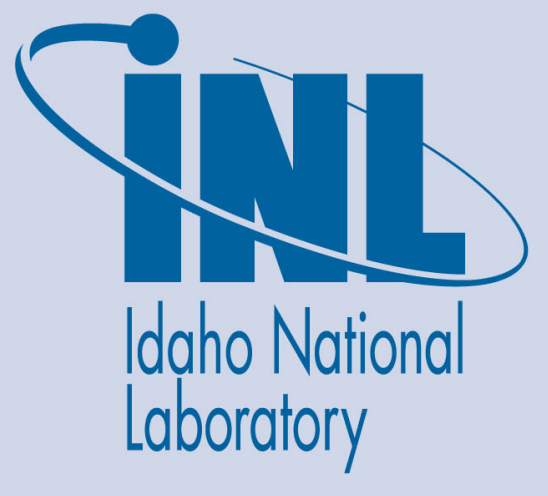

The INL is a U.S. Department of Energy National Laboratory operated by Battelle Energy Alliance 
INL/EXT-12-27593

\title{
Characterization of Advanced Preprocessed Materials (Hydrothermal)
}

\author{
Rachel Emerson \\ Garold Gresham
}

September 2012

\begin{abstract}
Idaho National Laboratory
Idaho Falls, Idaho 83415
\end{abstract}

http://www.inl.gov

Prepared for the

U.S. Department of Energy

Assistant Secretary for Energy Efficiency and Renewable Energy

Under DOE Idaho Operations Office

Contract DE-AC07-05ID14517 


\begin{tabular}{|l|l|}
\hline $\begin{array}{l}\text { ID\#: 2.1.1.8.A.DL.2 } \\
\text { Type: } \text { (DL) }\end{array}$ & $\begin{array}{l}\text { Completion Date: } 9 / 30 / 2012 \\
\text { Scheduled Completion: } 9 / 30 / 2012\end{array}$ \\
\hline Milestone Title: & Characterization of advanced preprocessed materials (Hydrothermal) \\
\hline Authors: & Rachel Emerson, Garold Gresham \\
\hline $\begin{array}{l}\text { Project Name: } \\
\text { Project Leader: }\end{array}$ & Optimized Preprocessing for Biochemical Conversion \\
\hline Key Words: & mild hydrothermal treatment, advanced preprocess, corn stover \\
\hline
\end{tabular}

\section{Objective:}

The objective of the optimized preprocessing effort is to optimize the efficiency of conversion processes through advanced preprocessing of feedstock materials. This report focuses on hydrothermal carbonization (HTC) at a reduce severity as one possible approach to optimize conversion efficiency by reducing the overall ash content in the biomass. This effort specifically focuses on using mild hydrothermal treatment options (temperature, water loading, and residence time) to reduce the intrinsic ash content; chelating options were also investigated as one of the mild hydrothermal treatment parameters.

HTC is a well established pretreatment for bioconversion, specifically, thermochemical conversion processes. It involves moderate temperatures $\left(200\right.$ to $\left.260^{\circ} \mathrm{C}\right)$ and pressures $(200$ to 700 psia) over an aqueous solution of biomass for at a set period of time (10 to 20 minutes or less $)^{1}$. In a typical HTC process the resulting oxygen and hydrogen are reduced in the product while the carbon content is unchanged or slightly reduced. The product and product yield are impacted by the speed of the heat transfer to the feedstock particles, the temperature of the reaction, and the residence time ${ }^{2}$. Many chemical reactions occur during the hydrothermal process (complex reaction networks, many parallel reactions occur simultaneously), but the process is governed primarily by dehydration and decarboxylation ${ }^{3}$. The proposed thermal process for this study is a variation of the HTC process; it will focus on the lower end of the temperature range $\left(170-230^{\circ} \mathrm{C}\right)$. The purpose of reducing the heat of the treatment is to better retain an 'intact' feedstock that resembles the original material while reducing components that negatively impact conversion processes, specifically the ash content. Because the objective of this project is to create advanced material for a biochemical conversion platform there is a focus on retaining the overall carbohydrate content within the feedstock itself, reducing the ash content, and ideally reducing the recalcitrance of the material as well.

\section{Expected Outcome:}

Through the collaborative research with the University of Nevada, Reno (UNR), the expectation was to identify succinct operational hydrothermal treatment parameters that would reduce the overall ash content of corn stover, reduce recalcitrance, and improve conversion efficiency. The INL provided the UNR with milled corn stover. UNR then prepare the mild hydrothermally treated materials in a bench-top Parr reactor. INL collaboratively investigate preprocessing options and characterize the advanced treated materials. Optimization efforts focused on 
identifying and enhancing the physiochemical feedstock characteristics to improve bioconversion performance, specifically the reduction of ash content.

\section{Progress:}

\section{Materials and Methods}

\subsection{Material}

Three bales of corn stover were procured from Emmetsburg, Iowa and were ground to $1 / 4$ inch using a Bliss Hammermill (Ponca City, OK). The material was then sequentially ground to $2 \mathrm{~mm}$ using the Thomas Wiley Model 4 Mill (Ramsey, MN). Samples were stored in 5-gallon buckets until analysis and/or treatment.

\subsection{Hydrothermal Treatment}

This was the procedure followed for all hydrothermal carbonization treatments of the $2 \mathrm{~mm}$ ground corn stover. The treatments were performed in a 2L Parr bench-top reactor (Moline, IL) model no. 4642. The reactor vessel is made of $316 \mathrm{SS}$ and it is rated for up to 2900 psi pressure and up to $350^{\circ} \mathrm{C}$. Heat is provided by a Calrod type heater with $1100 \mathrm{~W}$ and $10 \mathrm{amp}$ current from Parr Instrument (Moline, IL). The heating rate is $6-8^{\circ} \mathrm{C} / \mathrm{min}$ when the reactor is fully loaded. The temperature of the reactor was controlled using a CS2110 controller with a J type thermocouple from Omega (Stamford, CT). The reactor pressure was not controlled, but was indicated by a pressure gauge, with pressure ranging from 1-5 MPa. For the treatment, nitrogen of $80 \mathrm{~mL}$ (STP)/min was passed through the reactor for 10 min to purge oxygen. Next, the reactor was placed into the heater. An axial impeller, powered by a 1/25 HP motor with $1800 \mathrm{rpm}$, was used in the reactor with a rotating speed of 200-400 rpm. The reactor was heated to the desired temperature, and then cooled rapidly by immersion in an ice-water bath. When the temperature inside of the reactor dropped to $20^{\circ} \mathrm{C}$, the reactor was removed from the ice water bath. The lid was removed, and gases were released to the atmosphere. The solid output was filtered by a 325 stainless steel mesh (SS 316). The $\mathrm{pH}$ of the liquid product was measured by a hand-held digital $\mathrm{pH}$ meter.

\subsubsection{Mild Hydrothermal Treatment (mHTP)}

For each run, a mixture of corn stover and water with a ratio of 1:5 or 1:15 w/w was loaded into the reactor. The reaction was held for 5-20 min at temperatures ranging from $170-230^{\circ} \mathrm{C}$. After the reactor was cooled, the solid product was washed with $500 \mathrm{~mL}$ of DI water (at room temperature) to remove the sugars and any inorganic material from the surface. The wet solid was put in a drying oven at $105^{\circ} \mathrm{C}$ for 24 hours before further analysis. Liquid fractions from the $170^{\circ} \mathrm{C}$ treatments were collected for further analysis.

\subsubsection{Na-Citrate Mild Hydrothermal Treatment}


Na-citrate was added to the reactor in $0.05 \mathrm{~g} / \mathrm{g}$ and $0.1 \mathrm{~g} / \mathrm{g}$ with the biomass. The reaction time was held at $130^{\circ} \mathrm{C}$ for 2 hours; as citrate has a degradation temperature of $175^{\circ} \mathrm{C}$. The solid samples were rinsed with both acetone and DI water before and after the reaction. These washings were collected for further analysis.

\subsection{Analyses}

\subsubsection{Compositional Analysis}

Chemical analysis of the untreated corn stover and the hyrothermal treated samples was conducted using the following standard methods from the NREL biomass program: Summative Mass Closure Laboratory Analytical Procedure (LAP) Review and Integration: Feedstocks ${ }^{4}$; Determination of Ash in Biomass ${ }^{5}$; Determination of Acid Soluble Lignin Concentration Curve by UV-Vis Spectroscopy ${ }^{6}$; Determination of Structural Carbohydrates and Lignin in Biomass ${ }^{7}$; Standard Test Method for Moisture, Total Solids, and Total Dissolved Solids in Biomass Slurry and Liquid Process Samples ${ }^{8}$; Preparation of Samples for Compositional Analysis 9 .

\subsubsection{Proximate Analysis}

The hydrothermal treated and untreated corn stover were analyzed with a LECO TGA701 Thermogravimetric Analyzer (St. Joseph, MI) for moisture, volatile, ash, and fixed carbon content ${ }^{10}$. The instrument was heated to $107^{\circ} \mathrm{C}$ and held this temperature until a constant mass was reached under a $10 \mathrm{lpm}$ UHP nitrogen flow to measure the moisture content. The crucibles were capped with ceramic covers and the temperature was then ramped to $950^{\circ} \mathrm{C}$ and held here for $7 \mathrm{~min}$ to determine volatiles. The instrument cooled to $600^{\circ} \mathrm{C}$, the covers were removed and the gas was switched to a flow of $3.5 \mathrm{lpm}$ of oxygen. The temperature was then increased to $750^{\circ} \mathrm{C}$ and was held until a constant mass was reached for an ash measurement. Fixed carbon was determined by the weight loss between the volatile measurement and the ash measurement.

\subsubsection{Ultimate Analysis}

The determination of $\mathrm{CHN}^{11}$ and $\mathrm{S}^{12}$ for both the treated and untreated corn stover was performed using a LECO TruSpec CHN and S add-on module (St. Joseph, MI). Oxygen was determined by difference ${ }^{11}$. The moisture from the proximate analysis (performed simultaneously) was used to correct for a 'dry basis' analysis.

\subsubsection{Calorific Content}

The higher heating value (HHV) was determined by a LECO AC600 Semi-Automatic Isoperibol Calorimeter (St. Joseph, MI) ${ }^{13}$. The moisture from the proximate analysis was used to correct for a 'dry basis' analysis.

\subsubsection{Induced coupled plasma-optical emission spectroscopy (ICP-OES) Analysis}


A Thermo Scientific iCAP 6000 Series ICP Emission Spectrometer (Waltham, MA) was used to analyze the elements $\mathrm{K}, \mathrm{Mg}, \mathrm{Mn}, \mathrm{Na}$, and $\mathrm{Si}$ in the liquid fractions from the thermal treatment for a select number of samples. The only sample preparation required was filtering through a $0.2 \mathrm{~mm}$ acrodisc Fisher Scientific filter. All standards used in the instrument met the ISO 9001 qualifications.

\subsubsection{Ion Chromatography (IC) Analysis}

The liquid fractions and washings were also analyzed for their anions using IC analysis. A Dionex ICS-3000 instrument was used to measure the anions $\mathrm{F}, \mathrm{Cl}, \mathrm{Br}, \mathrm{NO}_{3}$, and $\mathrm{SO}_{4}$ with a Dionex ASRS 300 (anion self-regenerator suppressor) and Dionex IonPac AS18 anion-exchange column (Sunnyvale, CA). The sample preparation was the sample for the ICP-OES analysis. All standards used in the procedure met the ISO 9001 qualifications.

\section{Results and Discussion}

\subsection{Mild Hydrothermal Treated (mHTP) Samples}

The focus of this research was to determine which hydrothermal treatment parameters reduce ash content while retaining other favorable biochemical conversion characteristics. The original proposed sample treatments (Table 1) followed the standard procedure for mild hydrothermal treatment; using only biomass and water in the reactor. Figure 1 shows the changes in the samples' appearances in relation to the time and temperature. The treatments at $170^{\circ} \mathrm{C}$ did not seem to have a large impact on the composition of the corn stover (Fig. 2). The only notable change for the $170^{\circ} \mathrm{C}$ samples is a decrease of the water extractives with the increase in residence time. This is an expected outcome as the reaction occurs in heated water and would ultimately extract more water soluble components during increased residence times that would not be included in the solid biomass product. As the reaction temperature increased to $200^{\circ} \mathrm{C}$ and $230^{\circ} \mathrm{C}$, the hemi-cellulose (xylan, galactan, and arabinan) begins to degrade (Fig. 2). The degraded hemi-cellulose is most likely a contributing factor to the obvious increase of total extractives at these higher temperatures. The lignin and glucan values are not affected by the increase of temperature. The compositional analysis results for ash were analyzed without the other components to identify trends more easily (Fig. 3). Samples $170^{\circ} \mathrm{C} ; 20 \mathrm{~min} ; 5: 1$ and $170^{\circ} \mathrm{C} ; 5 \mathrm{~min} ; 15: 1$ show a slight reduction in the whole ash $(8.22 \%$ to $7.50 \%)$ when compared to the ash content from the untreated material, but this value is still higher than the set specification

for further conversion processes of $5-6 \% \mathrm{ash}^{14}$. The reduction in the whole ash could also be an impact of the soil being washed from the treated samples and remaining on the untreated as the whole ash analysis is done prior to the extraction step. The structural (physiological) ash, measured after the extraction process, was not reduced in these samples when compared to untreated corn stover. 
The proximate, ultimate, and calorific analysis show that with an increase in treatment severity (increase in reaction time and temperature) the treated material increased in ash, carbon, and gross calorific value and decreased in volatiles and oxygen (Table 2-4). These trends are typical for most heat treatment preprocessing techniques in which the end goal is to create a high energy-density product for thermal conversion processes ${ }^{15}$.

\subsection{Liquid Fraction Analysis}

Because the original treatments did not reduce the overall ash content, the liquid fractions from the treatments were analyzed to better understand what was being leached from the solid sample. The liquid fractions from the four $170^{\circ} \mathrm{C}$ treatments (Table 1) were analyzed using ICP-OES (Inductively Coupled Plasma-Optical Emission Spectrometry) and IC (Ion Chromatography) for inorganic components (Table 5) and HPLC for the carbohydrate and organic acid content (Table 6). As the residence time increases the amount of $\mathrm{K}, \mathrm{Mg}$, and $\mathrm{Si}$ increase while the $\mathrm{F}$ and $\mathrm{Cl}$ decrease. Though the overall ash content is not reduced significantly by the original proposed heat treatment, the conversion process inhibitors, such as the alkali metals and silicate, are being removed to a greater extent with the increase in reaction time even the lowest temperature treatment. The HPLC analysis shows that as the treatment time increases the hemi-cellulosic content in the liquid fraction increases also. This trend is expected as there was a decrease in the water extractives (which contain monomeric sugars) in the compositional analysis of these samples (Fig. 2). The negative effect of this result is that any removal of glucan from the final pretreated material will not contribute to the lignocellulosic to ethanol conversion process.

\subsection{Na-citrate treated samples}

The originally proposed heat pretreatment matrix was not successful in reducing the overall ash content in the biomass; therefore, another parameter was introduced. Sodium citrate, a chelator, was used in both $0.05 \mathrm{~g} / \mathrm{g}$ Na-Citrate/biomass and $0.1 \mathrm{~g} / \mathrm{g}$ Na-Citrate/biomass ratios to remove metal ions from the biomass. Chelators have been historically used to remove contaminants (such as metal) from soil. The reactions were performed at $130^{\circ} \mathrm{C}$ for 2 hours. The initial analyses have shown a reduction in the structural ash content from $6.37 \%$ to $1.95 \%$ for the $0.05 \mathrm{~g} / \mathrm{g}$ Na-citrate/biomass sample (Fig. 4). The new heat treatment does not seem to alter the other constituents (e.g. cellulose, hemicelluloses, and lignin) of the corn stover (Fig. 5) as it is performed at a low temperature (the degradation temperature for citrate is less than $150^{\circ} \mathrm{C}$ ). The samples also retain a similar (untreated) appearance when compared to the original corn stover (Fig. 6). 
Table 1. Matrix of the original hydrothermal pretreatment conditions for $\mathbf{2} \mathbf{m m}$ ground corn stover. The parameters are time, temperature, and water to biomass ratio within the $2 \mathrm{~L}$ Parr reactor.

\begin{tabular}{cccc}
\hline Sample \# & Temperature $\left({ }^{\circ} \mathrm{C}\right)$ & Time $(\mathrm{min})$ & Water:Biomass \\
\hline Untreated & N/A & N/A & N/A \\
1 & 170 & 5 & $5: 1$ \\
2 & 200 & 5 & $5: 1$ \\
3 & 230 & 5 & $5: 1$ \\
4 & 170 & 10 & $5: 1$ \\
5 & 170 & 20 & $5: 1$ \\
6 & 200 & 20 & $5: 1$ \\
7 & 230 & 20 & $5: 1$ \\
8 & 170 & 5 & $15: 1$ \\
\hline
\end{tabular}



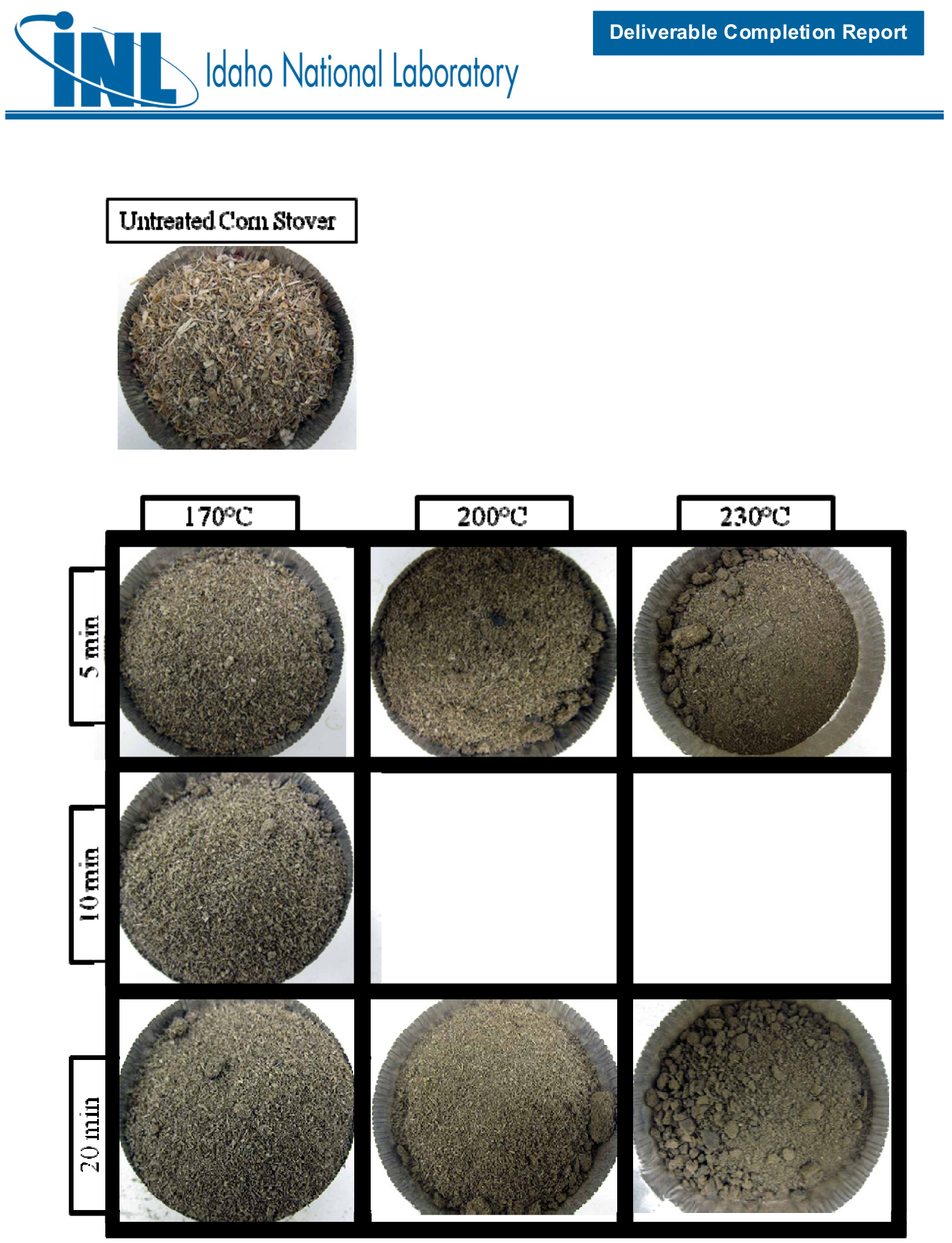

Figure 1 Mild Hydrothermal Treatments ( $\mathrm{mHTP}$ ) conditions for $\mathbf{2 m m}$ ground corn stover compared to the untreated corn stover. The parameters shown are time and temperature. Sample \#8 (Table 1) is not shown here. 


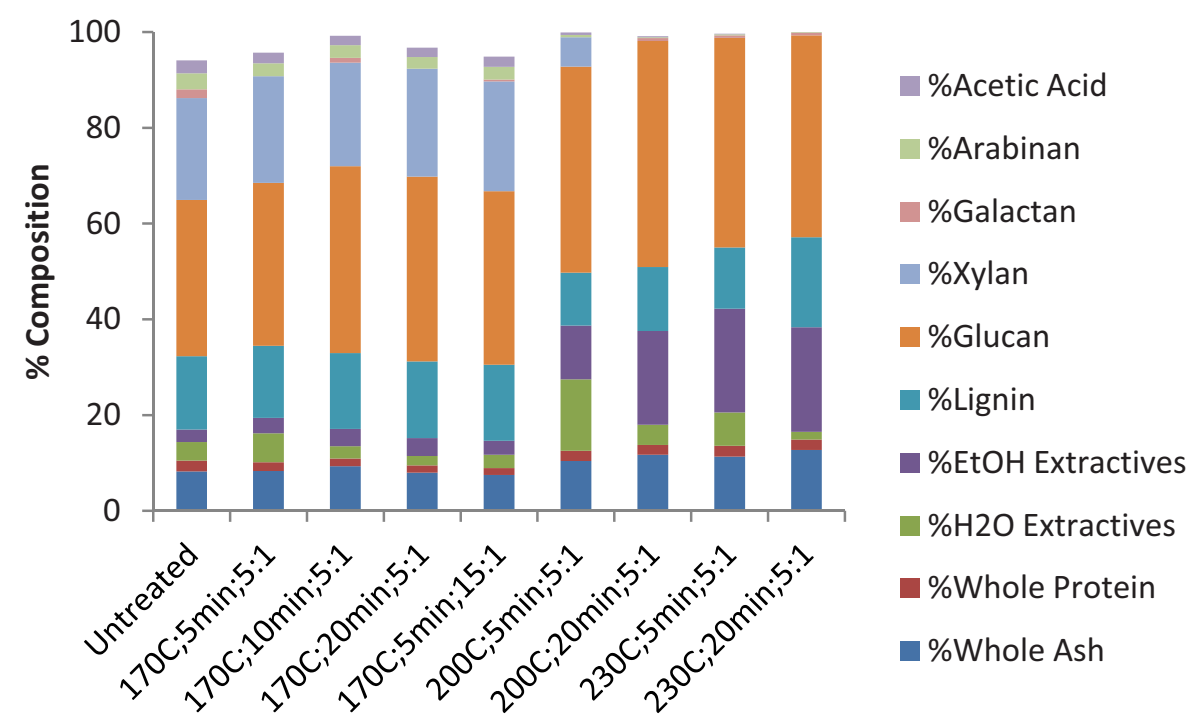

Figure 2. Compositional analysis of mild Hydrothermal Treatment (mHTP) treated corn stover samples from the original experimental design matrix (Table 1).

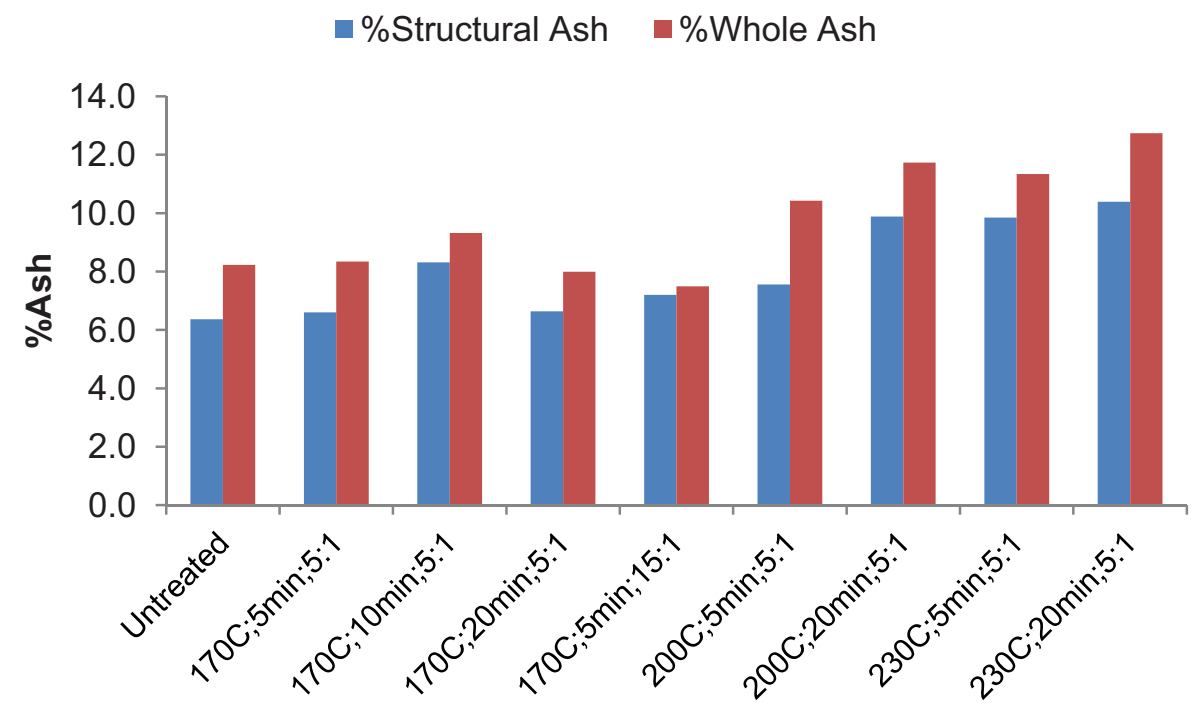

Figure 3. Structural ash and whole ash comparison for the mild Hydrothermal Treatment (mHTP) treated samples from the compositional analysis in the original experimental design matrix (Table 1). 
Table 2. Proximate analysis of mild Hydrothermal Treatment (mHTP) treated corn stover samples on a dry basis measured by a Thermogravimetric Analyzer (TGA) (n=3, mean \pm SD).

\begin{tabular}{|c|c|c|c|c|}
\hline Treatment & $\%$ Moisture ${ }^{\mathrm{a}}$ & $\%$ Volatile & $\%$ Ash & $\%$ Fixed Carbon \\
\hline Untreated & $7.21 \pm 0.13$ & $78.11 \pm 0.84$ & $9.71 \pm 0.30$ & $12.18 \pm 0.55$ \\
\hline $170 \mathrm{C} ; 5 \mathrm{~min} ; 5: 1$ & $4.06 \pm 0.05$ & $78.66 \pm 1.59$ & $9.36 \pm 0.28$ & $11.98 \pm 1.42$ \\
\hline $200 \mathrm{C} ; 5 \mathrm{~min} ; 5: 1$ & $2.95 \pm 0.05$ & $77.20 \pm 0.09$ & $10.53 \pm 0.47$ & $12.27 \pm 0.54$ \\
\hline $230 \mathrm{C} ; 5 \mathrm{~min} ; 5: 1$ & $2.61 \pm 0.09$ & $72.04 \pm 0.42$ & $11.27 \pm 0.12$ & $16.68 \pm 0.42$ \\
\hline 170C; 10min; 5:1 & $3.17 \pm 0.02$ & $80.07 \pm 1.16$ & $10.03 \pm 0.50$ & $9.90 \pm 0.69$ \\
\hline $170 \mathrm{C} ; \min ; 5: 1$ & $2.42 \pm 0.18$ & $80.55 \pm 0.88$ & $9.48 \pm 0.37$ & $9.97 \pm 0.58$ \\
\hline 200C; 20min; 5:1 & $1.83 \pm 0.02$ & $74.38 \pm 0.72$ & $12.25 \pm 0.27$ & $13.37 \pm 0.93$ \\
\hline 230C; 20min; 5:1 & $0.94 \pm 0.03$ & $72.25 \pm 1.21$ & $11.96 \pm 0.18$ & $15.78 \pm 1.27$ \\
\hline $170 \mathrm{C} ; 5 \mathrm{~min} ; 15: 1$ & $2.15 \pm 0.08$ & $82.17 \pm 1.60$ & $9.00 \pm 0.46$ & $8.83 \pm 2.05$ \\
\hline
\end{tabular}

a $\%$ Moisture was measured by the TGA during the proximate analysis and then used to calculate the dry basis measurements of the other fuel property components.

Table 3. Ultimate analysis of mild Hydrothermal Treatment (mHTP) treated corn stover samples on a dry basis measured by a CHN/S Elemental Determinator $(n=3$, mean \pm SD).

\begin{tabular}{llllll}
\hline \multicolumn{1}{c}{ Treatment } & \%Hydrogen & \%Carbon & \%Nitrogen & \%Oxygen & \%Sulfur \\
\hline Untreated & $5.43 \pm 0.08$ & $44.49 \pm 0.70$ & $0.80 \pm 0.03$ & $39.53 \pm 0.68$ & $0.05 \pm 0.01$ \\
170C; $5 \mathrm{~min} ; 5: 1$ & $5.51 \pm 0.04$ & $44.43 \pm 0.44$ & $0.78 \pm 0.07$ & $39.89 \pm 0.48$ & $0.04 \pm 0.01$ \\
200C; 5min; 5:1 & $5.53 \pm 0.14$ & $44.97 \pm 0.54$ & $0.86 \pm 0.03$ & $38.06 \pm 0.71$ & $0.04 \pm 0.00$ \\
230C; 5min; 5:1 & $5.40 \pm 0.28$ & $48.26 \pm 0.85$ & $0.79 \pm 0.09$ & $34.23 \pm 1.21$ & $0.04 \pm 0.01$ \\
170C; 10min; 5:1 & $5.61 \pm 0.15$ & $44.27 \pm 0.34$ & $0.77 \pm 0.04$ & $39.28 \pm 0.27$ & $0.04 \pm 0.00$ \\
170C; 20min; 5:1 & $5.63 \pm 0.03$ & $44.60 \pm 0.26$ & $0.77 \pm 0.06$ & $39.50 \pm 0.23$ & $0.03 \pm 0.00$ \\
200C; 20min; 5:1 & $5.46 \pm 0.04$ & $46.86 \pm 0.17$ & $0.87 \pm 0.06$ & $34.52 \pm 0.24$ & $0.04 \pm 0.00$ \\
230C; 20min; 5:1 & $5.41 \pm 0.03$ & $48.25 \pm 0.25$ & $0.84 \pm 0.02$ & $33.50 \pm 0.26$ & $0.05 \pm 0.01$ \\
170C; 5min; 15:1 & $5.65 \pm 0.07$ & $44.71 \pm 0.30$ & $0.72 \pm 0.01$ & $39.89 \pm 0.35$ & $0.03 \pm 0.00$ \\
\hline
\end{tabular}


Table 4. Gross calorific content (HHV) and net calorific content (LHV) for mild Hydrothermal Treatment (mHTP) treated corn stover samples on a dry basis measured by Semi-Automatic Isoperibol Calorimeter $(\mathrm{n}=\mathbf{3}, \operatorname{mean} \pm \mathrm{SD})$.

\begin{tabular}{lll}
\multicolumn{1}{c}{ Treatment } & HHV (BTU/lb) & LHV (BTU/lb) \\
\hline Untreated & $7722.19 \pm 37.85$ & $6349.04 \pm 37.85$ \\
170C; 5min; 5:1 & $7498.88 \pm 33.11$ & $6195.76 \pm 33.11$ \\
200C; 5min; 5:1 & $7658.53 \pm 28.68$ & $6379.56 \pm 28.68$ \\
230C; 5min; 5:1 & $8232.09 \pm 11.61$ & $6992.83 \pm 11.61$ \\
170C; 10min; 5:1 & $7516.34 \pm 23.96$ & $6215.20 \pm 23.96$ \\
170C; 20min; 5:1 & $7515.65 \pm 21.17$ & $6228.41 \pm 21.17$ \\
200C; 20min; 5:1 & $7991.04 \pm 14.28$ & $6759.23 \pm 14.28$ \\
230C; 20min; 5:1 & $8210.03 \pm 14.89$ & $7012.68 \pm 14.89$ \\
170C; 5min; 15:1 & $7479.99 \pm 7.31$ & $6195.18 \pm 7.31$ \\
\hline
\end{tabular}

Table 5 Induced coupled plasma-optical emission spectroscopy (ICP-OES) and Ion Chromatography (IC) analysis of the liquid fractions from the $170^{\circ} \mathrm{C}$ mild Hydrothermal Treatments (mHTP).

\begin{tabular}{ccccccccccccc}
\hline & \multicolumn{1}{c}{ ICP-OES Analysis } \\
Liquid Fractions & $\begin{array}{c}\mathrm{K} \\
(\mathrm{mg} / \mathrm{mL})\end{array}$ & $\begin{array}{c}\mathrm{Mg} \\
(\mathrm{mg} / \mathrm{mL})\end{array}$ & $\begin{array}{c}\mathrm{Mn} \\
(\mathrm{mg} / \mathrm{mL})\end{array}$ & $\begin{array}{c}\mathrm{Na} \\
(\mathrm{mg} / \mathrm{mL})\end{array}$ & $\begin{array}{c}\mathrm{Si} \\
(\mathrm{mg} / \mathrm{mL})\end{array}$ & $\begin{array}{c}\mathrm{F} \\
(\mathrm{mg} / \mathrm{mL})\end{array}$ & $\begin{array}{c}\mathrm{Cl} \\
(\mathrm{mg} / \mathrm{mL})\end{array}$ & $\begin{array}{c}\text { IC Analysis } \\
(\mathrm{mg} / \mathrm{mL})\end{array}$ & $\begin{array}{c}\mathrm{NO}_{3} \\
(\mathrm{mg} / \mathrm{mL})\end{array}$ & $\begin{array}{c}\mathrm{SO} \mathrm{S}_{4} \\
(\mathrm{mg} / \mathrm{mL})\end{array}$ \\
\hline 170C;5min;5:1 & 1.012 & 0.113 & 0.00519 & 0.0164 & 0.0147 & 0.1222 & 0.3485 & 0.0001 & 0.0666 & 0.0001 \\
$170 \mathrm{C} ; 10 \mathrm{~min} ; 5: 1$ & 0.956 & 0.113 & 0.00580 & 0.0160 & 0.0176 & 0.1505 & 0.3138 & 0.0001 & 0.0587 & 0.0001 \\
$170 \mathrm{C} ; 20 \mathrm{~min} ; 5: 1$ & 1.087 & 0.134 & 0.00480 & 0.0200 & 0.0288 & 0.0437 & 0.2302 & 0.0075 & 0.0679 & 0.0001 \\
$170 \mathrm{C} ; 5 \mathrm{~min} ; 15: 1$ & 0.453 & 0.041 & 0.00364 & 0.0185 & 0.0129 & 0.0591 & 0.1371 & 0.0001 & 0.0089 & 0.0001 \\
\hline
\end{tabular}

Table 6. High Pressure Liquid Chromatoghaphy (HPLC) analysis for total carbohydrate and organic acid content of the liquid fractions from the $170^{\circ} \mathrm{C}$ mild Hydrothermal Treatments (mHTP).

\begin{tabular}{|c|c|c|c|c|c|c|c|}
\hline \multirow[b]{2}{*}{ Liquid Fractions } & \multicolumn{5}{|c|}{$\underline{\text { Total Carbohydrates }}$} & \multicolumn{2}{|c|}{$\underline{\text { Organic Acids }}$} \\
\hline & $\begin{array}{l}\text { Glucan } \\
(\mathrm{mg} / \mathrm{mL})\end{array}$ & $\begin{array}{c}\text { Xylan } \\
(\mathrm{mg} / \mathrm{mL})\end{array}$ & $\begin{array}{l}\text { Galactan } \\
(\mathrm{mg} / \mathrm{mL})\end{array}$ & $\begin{array}{l}\text { Arabinan } \\
(\mathrm{mg} / \mathrm{mL})\end{array}$ & $\begin{array}{l}\text { Fructan } \\
(\mathrm{mg} / \mathrm{mL})\end{array}$ & $\begin{array}{c}\text { Acetic Acid } \\
(\mathrm{mg} / \mathrm{mL})\end{array}$ & $\begin{array}{c}\text { Formic Acid } \\
(\mathrm{mg} / \mathrm{mL})\end{array}$ \\
\hline 170C;5min;5:1 & 0.733 & 1.040 & 0.516 & 0.668 & 0.022 & 0.505 & 0.125 \\
\hline 170C;10min;5:1 & 0.584 & 1.363 & 0.422 & 0.670 & 0.017 & 0.437 & 0.098 \\
\hline $170 \mathrm{C} ; 20 \mathrm{~min} ; 5: 1$ & 1.241 & 3.584 & 0.931 & 1.515 & 0.038 & 0.881 & 0.513 \\
\hline 170C;5min;15:1 & 0.343 & 0.447 & 0.235 & 0.304 & 0.012 & 0.321 & 0.097 \\
\hline
\end{tabular}




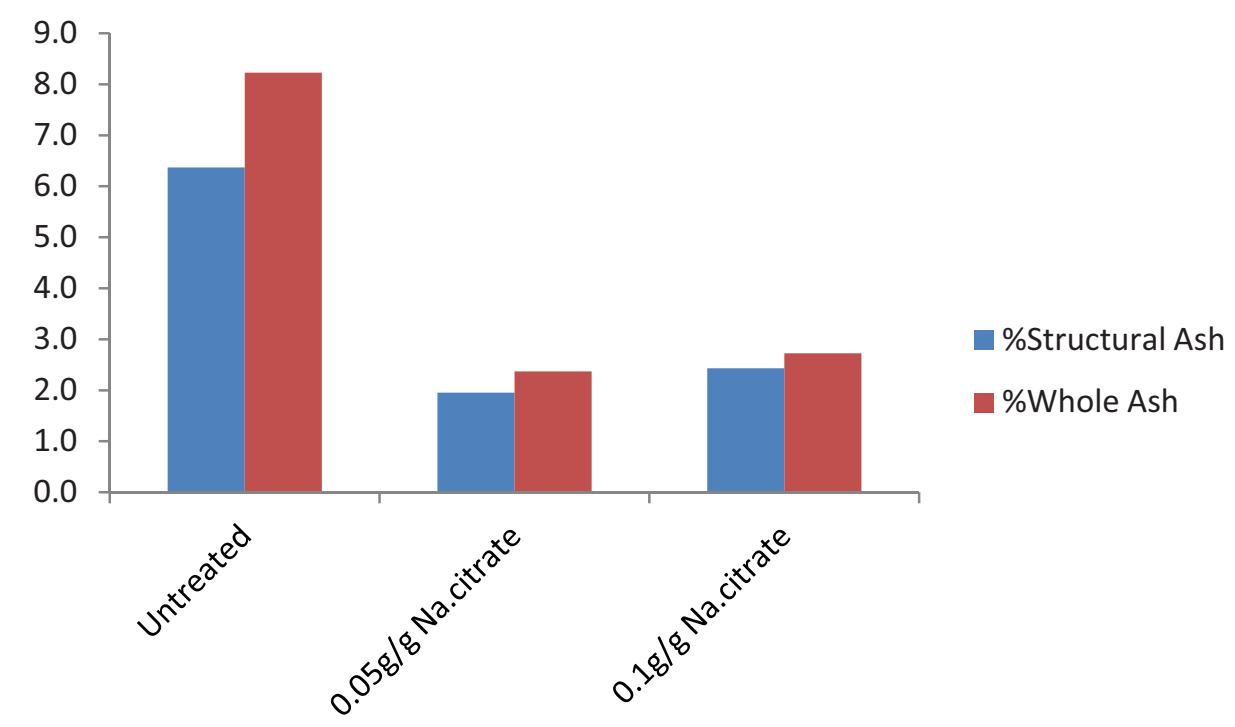

Figure 4. Structural ash and whole ash of untreated corn stover (original) compared to the mild Hydrothermal Treatments (mHTP) treated corn stover with $0.05 \mathrm{~g} / \mathrm{g}$ Na-citrate and $0.1 \mathrm{~g} / \mathrm{g}$ Na-citrate added to the reactor.

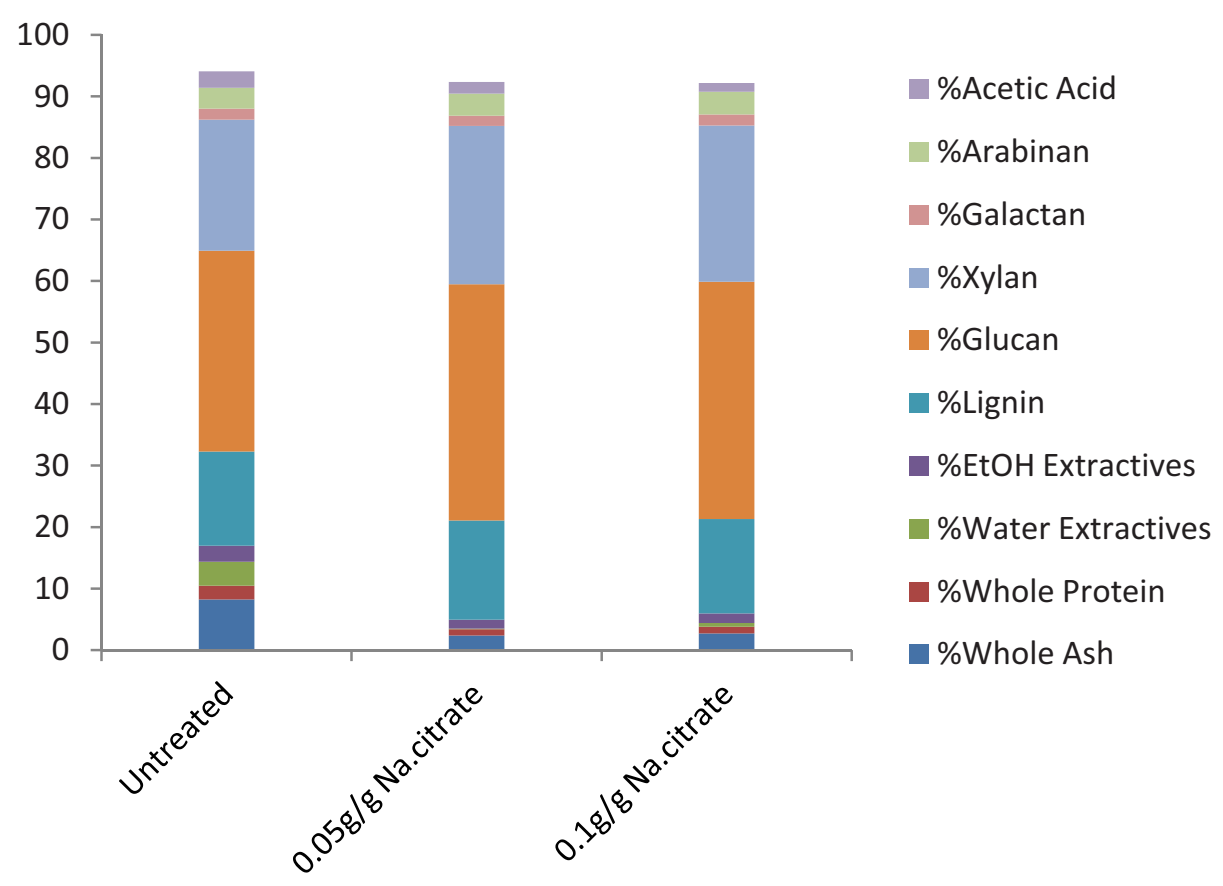

Figure 5. Compositional analysis of untreated corn stover (original) compared to the mild Hydrothermal Treatments (mHTP) treated corn stover with $0.05 \mathrm{~g} / \mathrm{g}$ Na-citrate and $0.1 \mathrm{~g} / \mathrm{g}$ Na-citrate added to the reactor. 


\section{Idaho National laboratory}

Deliverable Completion Report

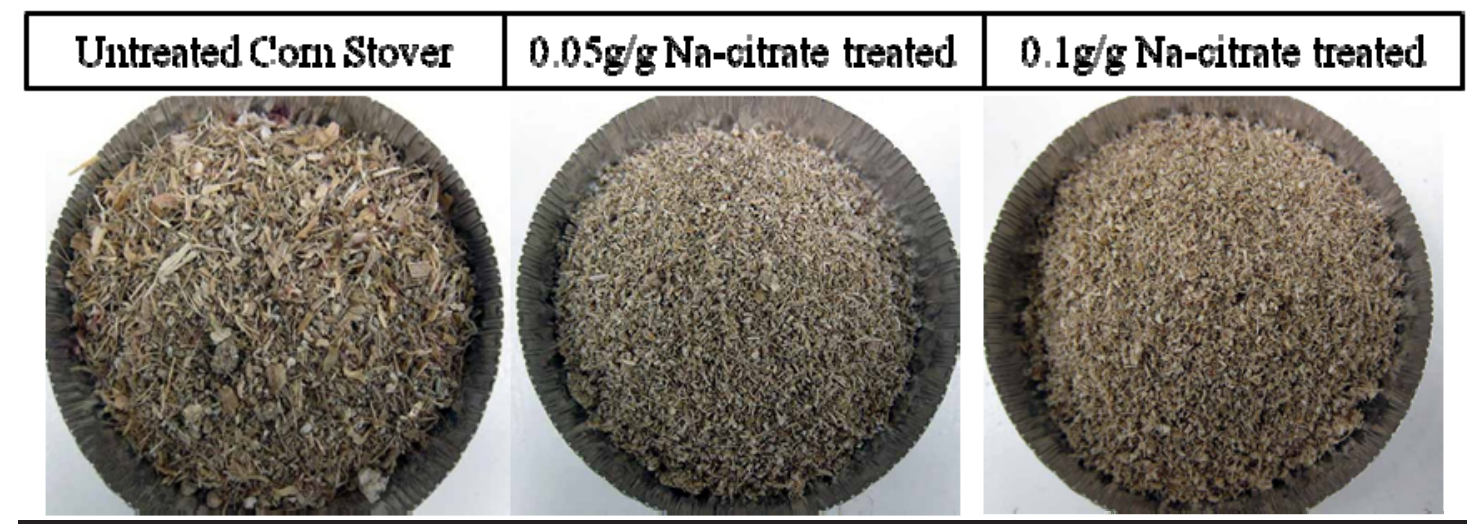

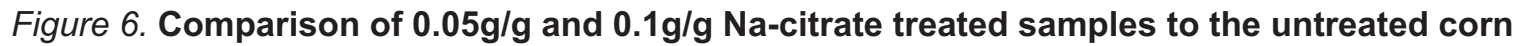
stover.

\section{Key Results:}

\section{Conclusion}

The initial hydrothermal treatment parameters did not achieve the proposed objective of this effort; the reduction of intrinsic ash in the corn stover. However, liquid fractions from the $170^{\circ} \mathrm{C}$ treatments was indicative that some of the elements routinely found in the ash that negatively impact the biochemical conversion processes had been removed. After reviewing other options for facilitating ash removal, sodium-citrate (chelating agent) was included in the hydrothermal treatment process, resulting in a $69 \%$ reduction in the physiological ash. These results indicated that chelation -hydrothermal treatment is one possible approach that can be utilized to reduce the overall ash content of feedstock materials and having a positive impact on conversion performance.

\section{Continuing Work}

Further analyses of the Na-citrate treated samples are being conducted to fully understand the impact of mild hydrothermal treatment, it's by-products, and the fractionation of the feedstock material. Further studies are proposed to optimize the treatment methodology. Conversion performance will be evaluated by NREL in FY13. In collaboration with UNR, the INL will produce a manuscript or manuscripts based on this research. The data currently being collected will be included in the FY13 quarterly write-up and the aforementioned paper. 


\section{References:}

1. L. Felix. Pretreatment Options for Thermochemical Biomass Conversion: Including Torrefaction and HTC, Gas Technology Institute, Biomass Technologies Course, July 2011.

2. J.Libra, K. Ro, C. Kammann, A. Funke, N. Berge, Y. Neubauer, M.-M. Titirici, C. Fühner, O. Bens, J. Kern, K.-H. Emmerich, Biofuels, 2011 2(1), 89

3. A. Funke, F. Zeigler, Biofuels, Bioprod. \& Bioref., 2010, 4, 160

4. J. Sluiter, A. Sluiter. Summative Mass Closure-laboratory analytical procedure (lap) review and integration: feedstocks, National Renewable Energy Laboratory, Golden, Colorado (2010, April) 14 pp. NREL Report No. TP-510-48087

5. D. Hyman, A. Sluiter, D. Crocker, D. Johnson, J. Sluiter, S. Black et al. Determination of Acid Soluble Lignin Concentration Curve by UV-Vis Spectroscopy, National Renewable Energy Laboratory, Golden, Colorado (2008, January) 13 pp., NREL Report No. TP-510-42617

6. A. Sluiter, B. Hames, R. Ruiz, C. Scarlata, J. Sluiter, D. Templetion. Determination of Ash in Biomass, National Renewable Energy Laboratory, Golden, Colorado (2008, January) 8 pp., NREL Report No. TP$510-42622$

7. A. Sluiter, B. Hames, R. Ruiz, C. Scarlata, J. Sluiter, D. Templetion et al. Determination of Structural Carbohydrates and Lignin in Biomass, National Renewable Energy Laboratory, Golden, Colorado (2010, June) 17 pp., NREL Report No.TP-510-42618

8. A. Sluiter, B. Hames, D. Hyman, C. Payne, R. Ruiz, C. Scarlata et al. Determination of total solids in biomass and total dissolved solids in lituid process samples, National Renewable Energy Laboratory, Golden, Colorado (2008, March) 9 pp., NREL Report No.TP-510-42621

9. B. Hames, R. Ruiz, C. Scarlata, A. Sluiter, J. Sluiter, D. Templetion. Preparation of samples for compositional analysis, National Renewable Energy Laboratory, Golden, Colorado (2010, August) 12 pp. NREL Report No. TP-510-42620

10. ASTM D 5142-09 (2010). Standard Test Method for Proximate Analysis of the Analysis Sample of Coal and coke by Instrumental Procedures, West Conshohocken, PA: ASTM International.

11. ASTM D 5373-10 (2010). Standard Test Methods fo Instrumental Determination of Carbon, Hydrogen, and Nitrogen in Laboratory Samples of Coal and Coke, West Conshohocken, PA: ASTM International.

12. ASTM D 4239-10 (2010). Standard Test Method for Sulfur in the Analysis Sample of Coal and Coke Using High-Temperature Tube Furnace Combustion, West Conshohocken, PA: ASTM International.

13. ASTM D 5865-10 (2010). Standard Test Method for Gross Calorific Value of Coal and Coke, West Conshohocken, PA: ASTM International. 
14. Aden A, Foust T: Technoeconomic analysis of the dilute sulfuric acid and enzymatic hydrolysis process for the conversion of corn stover to ethanol. Cellulose 16(4), 535-545 (2009).

15. W. Yan, T. Acharjee, C. Coronella, V. Vásquez: Thermal pretreatment of lignocellulosic biomass, Environ Program for Sustainable Energy 28, 435-440 (2009). 